
players. Pedagogy and Psychology of Sport. 2020;6(2):177-187. elSSN 2450-6605. DOI http://dx.doi.org/10.12775/PPS.2020.06.02.017 https://apcz.umk.pl/czasopisma/index.php/PPS/article/view/PPS.2020.06.02.017

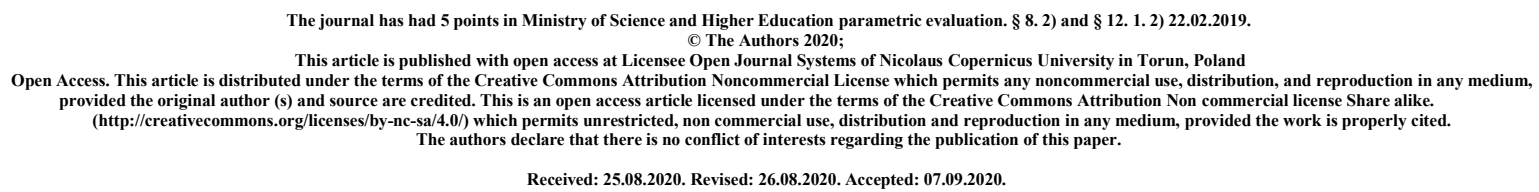

\title{
The assessment of Kinesiology Taping application in the reduction of menstrual pains among female basketball players
}

\author{
Magdalena Hagner-Derengowska ${ }^{1}$, Sławomir Gałęcki², Krystian Kałużny ${ }^{3}$, \\ Anna Kałużna ${ }^{3}$, Michał Cichosz ${ }^{4,5}$, Bartosz Kochański ${ }^{2}$, Xawery Zukow ${ }^{6}$
}

${ }^{1}$ Katedra Kultury Fizycznej, Wydział Nauk o Ziemi i Gospodarki Przestrzennej Uniwersytet Mikołaja Kopernika w Toruniu

${ }^{2}$ Bydgoska Szkoła Wyższa w Bydgoszczy

${ }^{3}$ Katedra Rehabilitacji, Wydział Nauk o Zdrowiu, Collegium Medicum im. L. Rydygiera w Bydgoszczy, Uniwersytet Mikołaja Kopernika w Toruniu

${ }^{4}$ PJ-MED Szpital rehabilitacyjny Popielówek

${ }^{5}$ Bonifraterskie Centrum Zdrowia Wrocław

${ }^{6}$ Uniwersytet Medyczny w Białymstoku

\section{SUMMARY.}

INTRODUCTION. A menstrual pain often contributes to the decline of a woman's life quality. It remains a serious problem in an everyday life, but also in a proffessional life of a sportwoman as it significantly affects the achieved results. Pharmacology is the most popular way to cease the menstrual pain. However, thanks to the development of physiotherapy, many methods of the menstrual pain management have been emerged and they are still evolving. It is in this regard especially noticebale that Kinesiology Taping should be paid rapt attention.

AIM OF THE RESEARCH. The aim of the research is to assess Kinesiology Taping application in the reduction of menstrual pains among female basketball players. 
MATERIALS AND METHODOLOGY. The reaserch was conducted in a group of 35 women aged 20-36 with regular menstrual cycles and who train basketball professionaly. This group was for itself the study group and the control group. The assessment was conducted twice: 1) the first menstrual cycle after the research inclusion (no medical intervention); 2) the second menstrual cycle with the application of Kinesiology Taping. 3 day prior menstrual bleeding Kinesiology Taping was used among the participants of the reasearch. The 'I'-shaped cutting technique was used. The tapes tension was $50 \%$ and they were on women's bodies for 7 days.

RESULTS. The average pain intensity in the NRS scale before the therapy was 5,525286 (median 6,00). Whereas after the therapy with the kinesiology taping application the decline of pain intensity was noted at the level of 3,428571 (median 3,00). The statistical analysis showed that the use of Kinesiology Taping had statistically significant $-p<0,05$ impact on the reduction of pain intensity in the NRS scale. The average value for the sum of the achieved points in the Laitinen pain questionnaire before the therapy was 9,428571; after the application of Kinesiology Taping 5,628571. Changes were also noted with the respect to the median- decline from 10,00 to 6,00 . The statistical analysis showed that the use of Kinesiology Taping had statistically significant $-p<0,05$ impact on the sum of the achieved points in the Laitinen pain questionnaire.

\section{CONCLUSIONS.}

1. Kinesiology Taping has a statistically significant impact on the reduction of the menstrual pain intensity in the NRS scale among female basketball players aged 20-36.

2. Kinesiology Taping has a statistically significant impact on the reduction of the menstrual pain intensity and frequency among female basketball players aged 20-36.

3. Kinesiology Taping has a statistically significant impact on the reduction of the painkillers intake among female basketball players aged 20-36.

4. Kinesiology Taping has a statistically significant impact on the reduction of the restraints of physical activity among female basketball players aged 20-36.

\section{KEY WORDS: the kinesiology taping, menstrual pain, basketball}

\section{INTRODUCTION.}

Increasingly often, women visit the physiotherapy pratices and clinics to deal with the menstrual pain, most of them addmit that the pain intensify regularly and gradualy. According to the literature, there is a wide range of factors which affect the aggrevation of menstrual 
pain, however, the etiopathogenesis of dysmenorrhea is not clearly stated. Among many predisposing factors, the most often mentioned are: the intensified uterine contracting function, the anatomical abnormalities of female reproductive system, the hormonal disorders, the improper sheeding of the endometrium [1,2].

The pain accompanying the menstruation is often present in the lower abdomen, the lumbar spine reaching even the sacral bone, groins and the lower limbs. The pain manifests itself in intense, rapid and interruptable uterus cramps, however, it can also be nausea, persistent and permanent. There are also additional symptoms accompanying the menstruation: a headache, insomnia, general tiredness, low mood and irritability [2].

A menstrual pain often contributes to the decline of a woman's life quality. The most popular way among women to cease the menstrual pain is pharmacology. However, thanks to the development of physiotherapy, many methods of the menstrual pain management have been emerged and they are still evolving. Special attention should be paid to the method called Kinesiology Taping [3]. The menstrual pain ailments are a serious problem and a challenge in sport as they have decisive effects on sport results.

\section{AIM OF THE RESEARCH.}

The aim of the research is the assessment of Kinesiology Taping application in the reduction of menstrual pains among female basketball players.

\section{MATERIALS AND METHODOLOGY.}

The reaserch was conducted in a group of 35 women aged 20-36 with regular menstrual cycles and who train basketball professionaly.

The criteria for inclusion: a regular menstrual cycle, menstrual pain, age brackets 20-36. The citeria fo exlusion: an allergy to Kinesiology Taping tapes, absence of a regular mentsrual cycle, cancer diseases, a pregnancy, operative intervensions carried out on the spine in the lumbar-pelvic area, traffic accidents or injuries, serious pathologies in the spine area which could affect the own research results.

The participants evaluated the effectiveness of Kinesiology Taping therapy with the use of the Laitinen pain questionnaire and the NRS scale.

The assessment was conducted twice:

1) the first menstrual cycle after the research inclusion (no medical intervention) 
2) the second menstrual cycle with the use of the Kinesiology Taping.

This group was for itself the study group and the control group. 3 day prior menstrual bleeding Kinesiology Taping was used among the participants of the research. The 'I'-shaped cutting technique was applied. The tapes tension was 50\%. The first incised tape was applied in the lower abdomen between first and second superior illiac spine, crosswise, its central part was tensed in a way which allowed tape's ending to remain not tensed. The shorter one was applied $0.5 \mathrm{~cm}$ below the navel. The way in which it was placed on the body was the same, only its position was vertical. Participants of the research had the stripes for seven days. The statistical analysis was made in Statistica 12.5. Statistical significance was taken as $\mathbf{p}<\mathbf{0 , 0 5}$.

\section{RESULTS.}

The average pain intensity in the NRS scale before the therapy was 5,525286 (median 6,00). After the application of Kiniesiology Taping in the therapy the decline of pain intensisty was noted at the level of 3,428571 (median 3,00). The reduction of minimum measurement value was observed from 3,00 to 0,00 and maximum measurment value from 10,00 to 8,00 . Moreover, it was noticed that the lower quartile decreased form 3,00 to 2,00 and the upper quartile from 7,00 to 2,00. The standard deviation of the assessed variable before the therapy equaled 2,077490, while after the therapy it equaled 2,145936.

Tab. I. The descriptive statistics - the NRS before and after.

\begin{tabular}{|c|c|c|c|c|c|c|c|}
\hline \multirow[b]{2}{*}{ Variable } & \multicolumn{7}{|c|}{ The descriptive statistics } \\
\hline & M & $\mathrm{Me}$ & Min & Max & $\begin{array}{l}\text { Lower } \\
\text { quartile }\end{array}$ & $\begin{array}{l}\text { Upper } \\
\text { quartile }\end{array}$ & SD \\
\hline $\begin{array}{l}\text { 7. the NRS scale } \\
\text { before }\end{array}$ & 5,514286 & 6,000000 & 3,000000 & 10,00000 & 3,000000 & 7,000000 & 2,077490 \\
\hline $\begin{array}{l}\text { 7.he NRS scale - } \\
\text { after }\end{array}$ & 3,428571 & 3,000000 & 0,000000 & 8,00000 & 2,000000 & 5,000000 & 2,145936 \\
\hline
\end{tabular}

The statistical analysis showed that the application of Kinesiology Taping had a statistical significant $-\mathbf{p}<\mathbf{0 , 0 5}$ impact on the reduction of the pain intensisty in the NRS scale.

Tab. II. The Wilcoxon test - The comparison of the results in the NRS scale before and after the implementation of Kinesiology Taping in the therapy. 


\begin{tabular}{|c|r|r|r|}
\hline \multirow{2}{*}{ The pair of variables } & \multicolumn{2}{|c|}{ Marked results are statistically significant $\mathrm{p}<, 05000$} \\
\cline { 2 - 4 } & $\mathrm{T}$ & $\mathrm{Z}$ & $\mathrm{p}$ \\
\hline $\begin{array}{l}\text { 7.the NRS scale \& 7.the } \\
\text { NRS scale- after }\end{array}$ & 0,00 & 4,622599 & $\mathbf{0 , 0 0 0 0 0 4}$ \\
\hline
\end{tabular}

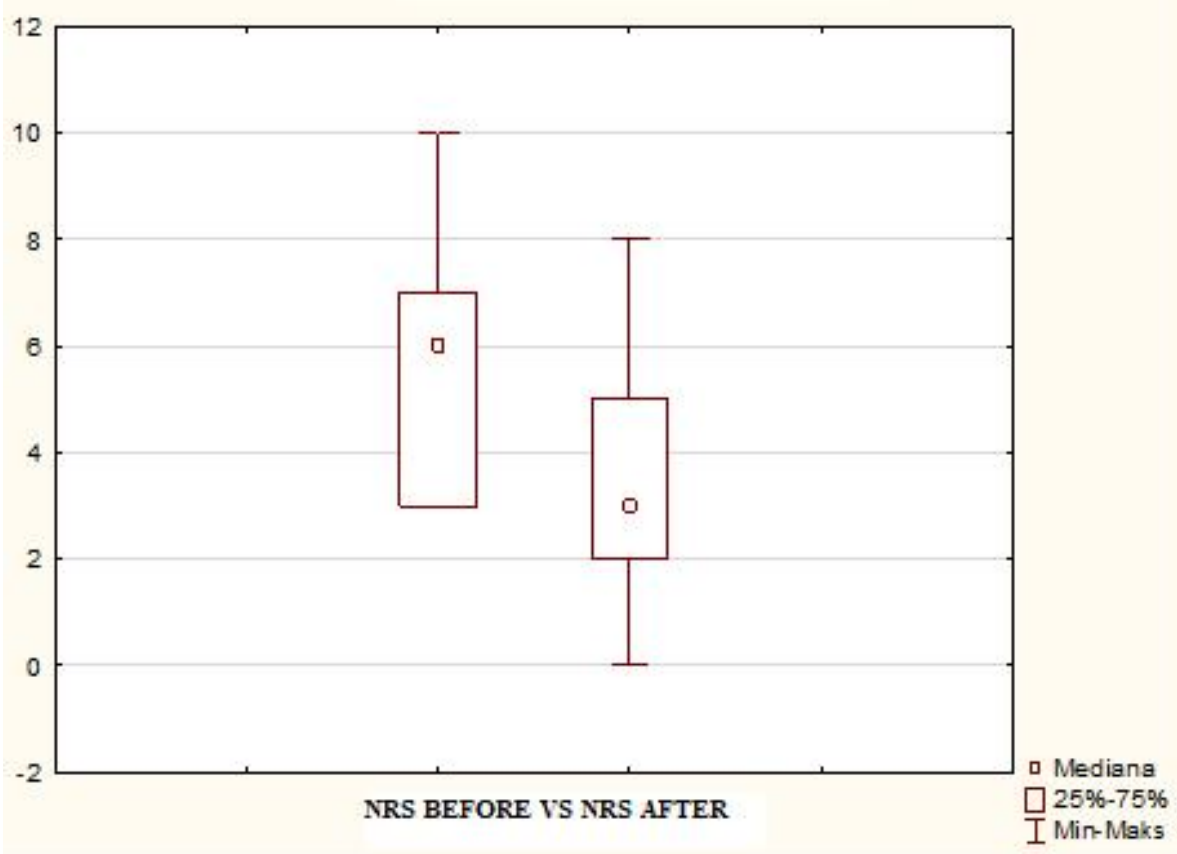

Dwg. 1 The comparison of the results in the NRS scale before and after the application of Kinesiology Taping in the therapy.

The Laitinen pain questionnaire enables the reseraches to assess the pain intensity, the pain frequency, the use of analgesics and the limitation of physical activity. The higher the result, the worse medical condition of the patient.

Tab. III. The Wilcoxon test - The comparison of the results in the NRS scale before and after the application of Kinesiology Taping in the therapy (Laitinen).

\begin{tabular}{|c|c|c|c|}
\hline \multirow[b]{2}{*}{ The pair of variables } & \multicolumn{3}{|c|}{$\begin{array}{l}\text { The Wilcoxon signed-rank test } \\
\text { Marked results are statistically significant } \\
\qquad p<, 05000\end{array}$} \\
\hline & $\mathrm{T}$ & Z & $\mathrm{p}$ \\
\hline $\begin{array}{l}\text { Laitinen before- Pain intensisty \& Laitinen after- } \\
\text { Pain intensity }\end{array}$ & 0.00 & 4.014509 & 0.000060 \\
\hline
\end{tabular}




\begin{tabular}{|l|r|r|r|}
\hline $\begin{array}{c}\text { Laitinen before- Pain frequency \& Laitinen after- Pain } \\
\text { frequency }\end{array}$ & 0,00 & 4,372373 & $\mathbf{0 , 0 0 0 0 1 2}$ \\
\hline $\begin{array}{c}\text { Laitinen before- Frequency of analgesics use \& } \\
\text { Laitinen after- Frequency of analgesics use }\end{array}$ & 0,00 & 4,014509 & $\mathbf{0 , 0 0 0 0 6 0}$ \\
\hline $\begin{array}{c}\text { Laitinen before przed- limitation of physical activity \& } \\
\text { Laitinen after- limitation of physical activity }\end{array}$ & 0,00 & 4,372373 & $\mathbf{0 , 0 0 0 0 1 2}$ \\
\hline
\end{tabular}

Tab. IV. The decriptive statistics - Laitinen Questionnaire- The sum before and after the therapy with the application of Kinesiology Taping

\begin{tabular}{|l|c|r|r|r|r|r|c|}
\hline \multirow{2}{*}{ Variable } & \multicolumn{6}{|c|}{ The descriptive statistics } \\
\cline { 2 - 7 } & $M$ & Me & Min & Max & $\begin{array}{r}\text { Lower } \\
\text { quartile }\end{array}$ & $\begin{array}{r}\text { Upper } \\
\text { quartile }\end{array}$ & SD \\
\hline $\begin{array}{l}\text { Laitinen before- the sum } \\
\text { of points }\end{array}$ & 9,428571 & 10,00000 & 4,000000 & 16,00000 & 6,000000 & 12,00000 & 3,508693 \\
\hline $\begin{array}{l}\text { Laitinen after- the sum of } \\
\text { points }\end{array}$ & 5,628571 & 6,00000 & 0,000000 & 12,00000 & 3,000000 & 8,00000 & 3,078251 \\
\hline \hline
\end{tabular}

The average vaule for the sum of points gained in the Laitinen Questionnaire before the therapy was 9,428571; after the use of Kinesiology Taping in the therapy 5,628571. The changes were also observed in the median - the decline from 10,00 to 6,00 . It was noticed that the minimum value decreased form 4,00 to 0,00 and the maximum value from 16,00 to 12,00. Moreover, it was observed that the lower quartile declined form 6,00 to 3,00 and the upper quartile from 12,00 to 8,00 . The standard deviation of the assessed variable before the therapy equaled 3,508693, while after the therapy it equaled 3,078251.

The statistical analysis showed that the application of Kinesiology Taping had a statistical significant $-\mathbf{p}<\mathbf{0 , 0 5}$ impact on the sum of values in the Laitinen questionnaire. The drawing below presents the comparison of the results in the Laitinen scale for the assessed variable before and after the therapy. 


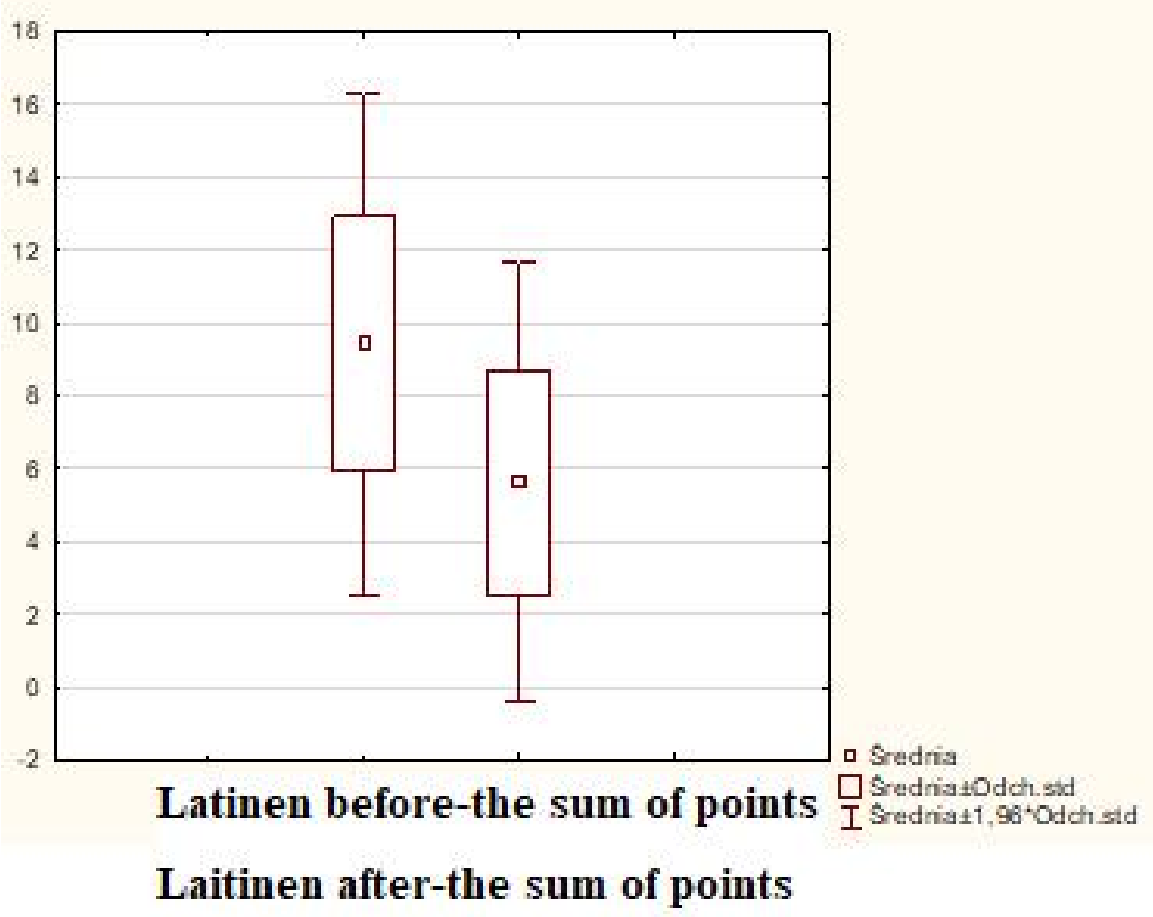

Dwg. 2. The comparison of the results- Laitinen Questionnaire- The sum before and after the therapy with the application of Kinesiology Taping.

\section{DISCUSSION.}

The pain associated with the menstruation is a common phenomenon and it affects many women. In the past dysmenorrhea was a taboo subject, whereas nowadays, it becomes increasingly frequent topic mentioned during the appointmet with the physiotherapist. The severity of pain may be different, however, sometimes it becomes acute and it impedes woman's everyday life functioning so that she even may be exluded from her professional life for couple of days. Besides movement limitations, other symptoms coexist and they affect not only physical activity, but also the psychological sphere i.e. general irritability, lack of concentration, low mood, insomnia, vomiting, headaches, etc. [4,5].

In the present study it was demonstarted that the use of Kinesiology Taping has a decisive effect on the decline of pain ailments and on life quality. In the current research, after the application of Kinesiology Taping, a statisticaly significant improvement was noticed in the aspects of the pain intensisty, the pain frequency, the use of pain killers and the physical activity.

In the research conducted by Tomasz Wilk, Magdalena Niewęgłowska-Wilk, Izabela Załęska, 40 women suffering from menstrual pain aged 20-35 had Kinesiology Tapes used, first in the area of navel and second in the lower abdomen area. 
Tapes were applied among 20 women 2 days prior the menstrual bleeding,whereas the rest of the group became a control group. During this research the VAS was used ( the visual and analogue scale). Kinesiology Taping was held on skin for 7 days. The research time was 3 months. The result unambigiously showed that in the group of 20 women, where Kinesiology Taping was implemented,the pain ailments declined. Before the research the average in the VAS scale was 6 , after 3 months the pain process cesead to 1 or even close to 0 . In the control group no imporovement was observed [6].

The effect of the menstrual pain ailments and their intensity is dependent on many factors, inter alia, the hormonal balance as every disorder may have a significant impact on the frequency of uterine contractions, hence on the increse of pain intensity. According to the literature, what is also important is the age of a woman and wheter or not she went into a labour. Anatomical disorders congenial or aquired i.e. a distortion or a defomation of female genital organs may be a direct reason for the occurrence of pathological pains around the abdominal area, which intensify several hours prior the menstruation, as a result of tumescence of genital organs, which, in turn, leads to the pressure on organs and tissues. Basic and routine tests in the gynecological examination room are of great importance. Sometimes women ignore the increased activity of the menstrual soreness, while the increase of pain ailments intensity and frequency may indicate a disease entity of genital organs. Among those which result in the growth of menstrual pains endometriosis and cancer are most often mentioned. The sooner the gynecologist establishes the accurate diagnosis, the more effective is the treatment and a woman may feel bigger comfort while the menstruation. Many women feel strong ailments assossiated not only with pre-menstruation period, but also with the menstruation period itself and they do not know where to seek help in order to minimalise this discomfort $[7,8,9,10,11]$.

Kinesiology Taping enables successful reduction of pain ailments in the abdominal area. It needs to be emphasised that it helps women to return to day-to-day activities. However, before Kinesiolgy Taping application a patient must visit a ginecologist in order to exclude a disease which may intensify the pain. Kinesiology Taping itself is a non-invasive, painless method which gains constantly growing popularity. Additional assets of this method are low cost of a single tape,which lasts for 5-6 applications (about 6 months), and a short list of contradicitons $[12,13]$.

According to the research, Kinesiology Taping is an efficient method to fight against the menstrual pains. Many women are very often exluded form the routine of everyday life. The use of Kinesiology Taping demostrated that the menstruation do not have 
to be such a dramatic experience for her to resign from the physical activity i.e. swimming. Every appointment of a woman with certain ailments at the physiotherapy practices is not only a chance to use this method, but also a possibility to conduct an interview during which the physiotherapist is able to detect alarming signals and refer the patient to a gynecologist for further examination [14].

The analysis of 10 most important basic life support systems of human body cardiovascular (CVS), respiratory (RS), nervous (NS), digestive (DS), endocrine (ES), immune (IS), excretory (EXS), brain (BS), musculo-skeletal (MSS), hematopoietic (HS) was carried out. Based on this analysis two levels of ensuring the reliability of organism's work were revealed: sequential and parallel.

The system of logical equations for reduced sequential system is: Ys1 = CVS RS BS, where is the notation for the conjunctions of set elements.

The system of logical equations for the reduced parallel system is: Ys2 = NS DS ES IS HS EXS MSS, where is the disjunction of the scheme elements.

Visualization of human STC changes the concept of the kinetics of age-related changes in the organism and the role of determinants of health as a stable factor accompanying a uniform, smooth transition from the most pronounced functions of the body to their gradual extinction.

For human STC is formulated the following regularity kinetics of involutionary processes: after 30 years of age in the human body morphological changes regress in arithmetic progression, and the functions of organs in a geometric one.

Assumption of health as a state redundancy of functions is suggested [15].

The research is devoted to the fundamental issue of medicine and biology - the study of factors limiting the life span of a person. As a model, the system of adaptation of the human body to the forces of natural gravity is chosen, the disadaptation to which manifests itself in falls and everyday injuries. The object of the study was the selection of severe fractures of bone tissue due to fall, taken in the age aspect. Statistical and meta-analytical research methods were used. It is shown that the age-related increase in mortality due to household falls, coming to severe bone fractures, is non-linear and increases in geometric progression. As a result of the coincidence of the age characteristics of bone fragility and age-related kidney function, an assumption is made about the role of involution of the renal tissue in the development of osteoporosis in the elderly and the need for a new approach to the prevention of osteoporosis and domestic injuries [16]. 
In consideration of the presented assessment, menstrual pain ailments are a serious problem and a challenge in sport as they affect the results. Kinesiology Taping is the effective method in the menstrual pain reduction and there is a strong need to disseminate the knowledge about it and to educate women in this regard.

\section{CONCLUSIONS.}

1. Kinesiology Taping has a statistically significant impact on the reduction of the menstrual pain intensity in the NRS scale among female basketball players aged 20-36.

2. Kinesiology Taping has a statistically significant impact on the reduction of the menstrual pain intensity and frequency among female basketball players aged 20-36.

3. Kinesiology Taping has a statistically significant impact on the reduction of the painkillers intake among female basketball players aged 20-36.

4. Kinesiology Taping has a statistically significant impact on the reduction of the the restraints of physical activity among female basketball players aged 20-36.

\section{REFERENCES}

1. Smith M.D, Russell A., Hodges P.W. Do incontinence, breathing difficulties, and gastrointestinal symptoms increas the risk of future back pain J Pain, 2009, 10(8), 876-886.

2. Wu J.M., Hundley A.F., Fulton R.G. i wsp. Forecasting the Prevalence of Pelvic Floor Disorders in U.S. Women: 2010 to 2050. Obstetrics \& Gynecology, 2009, 114(6) $1278-1283$

3. Śliwicki Z., Senderek T., (2009) Kinezjotaping - nowa metoda leczenia, Rehabilitacja w Praktyce nr 3 s. 18-20

4. H., Taping Medyczny, H.F.J. Pijnappel, 2012

5.. Kase K., Wallis J., Kase T., (2013), Clinical Therapeutic Applications of the Kinesio Taping Metod, Wyd. Kinesio Taping Association, Tokio

6. T. Wilk, M. Niewęgłowska-Wilk, I. Załęska: Kinesiology taping as an alternative to painkillers used for the reduction of menstrual pains. FP 2015;15(4);82-88).

7. Armario A.: Activation of the hypothalamic-pituitary-adrenal axis by addictive drugs: diQerent pathways, common outcome. Trends. Pharm. Sci., 2010, 31, 318-325

8. Copolov D.L., Helme R.D.: Enkephalins and endorphins. Clinical, pharmacological and therapeutic implications. Drugs, 2013, 26, 503-519. 
9. Koneru A., Satyanarayana S., Rizwan S.: Endogenous opioids: their physiological role and receptors. Glob. J. Pharmacol., 2009, 3, 149-153.

10. Baylis P., Robertson G.: Plasma vasopressin response to hypertonic saline infusion to assess posterior pituitary function. J. R. Soc. Med., 2013, 73, 255-260.30.

11. Baylis P.H., Zerbe R.L.: Arginine vasopressin response to insulin-induced hypoglycemia in man. J. Clin. Endocrinol. Metab., 2011, 53, 935-940.

12. Rutkowska E, Łepecki-Klusek C.The role ofphysical activity in preparing women for pregnancy and delivery in Poland. Health Care Women Int 2012; 23(8): 919-23.

13. Montenegro ML, Vasconcelos EC, Candido Dos Reis FJ, Nogueira AA, PoliNeto OB. Physical therapy in the management of women with chronic pelvic pain. Int J Clin Pract 2009; 62(2): 263-9.

14. Morris SN, Johnson NR. Exercise during pregnancy: a critical appraisal of the litera-ture. J Reprod Med 2015; 50(3): 181-8.

15. Gozhenko, A., Biryukov, V., Gozhenko, O., Zukow, W. Health as a space-time continuum. Journal of Education, Health and Sport, 2018; 8(11), 763-777. DOI: http://dx.doi.org/10.5281/zenodo.2657000.

16. Gozhenko, A., Biryukov, V., Muszkieta, R., Zukow, W. Physiological basis of human longevity: the concept of a cascade of human aging mechanism. Collegium antropologicum, 2018; 42(2), 139-146. 